\title{
Parametric Analysis of an Embankment Dam's Stability
}

\author{
Amjad Hussain Bhutto \\ Department of Civil Engineering \\ Quaid-e-Awam University of \\ Engineering Science and Technology \\ Nawabshah, Pakistan \\ amjadbhutto62@gmail.com
}

\author{
Shahnawaz Zardari \\ Department of Civil Engineering \\ Quaid-e-Awam University of \\ Engineering, Science \& Technology \\ Nawabshah, Pakistan \\ shahnawazzardari@gmail.com
}

\author{
Ghulam Shabir Bhurgri \\ Department of Civil Engineering \\ Quaid-e-Awam University of \\ Engineering Science and Technology \\ Nawabshah, Pakistan \\ ghulamshabirbhurgri14@gmail.com
}

\author{
Muhammad Auchar Zardari \\ Department of Civil Engineering \\ Quaid-e-Awam University of Engineering, Science \& \\ Technology, Nawabshah, Pakistan \\ muhammad.auchar@quest.edu.pk
}

\author{
Muhammad Munir Babar \\ Institute of Water Resources Engineering and Management \\ Mehran University of Engineering and Technology \\ Jamshoro, Sindh, Pakistan \\ mmunirbabar.uspcasw@faculty.muet.edu.pk
}

\author{
Riaz Bhanbhro \\ Department of Civil Engineering \\ Quaid-e-Awam University of Engineering Science and \\ Technology, Nawabshah, Pakistan \\ riaz@quest.edu.pk \\ Bashir Ahmed Memon \\ Department of Civil Engineering \\ Quaid-e-Awam University of Engineering Science and \\ Technology, Nawabshah, Pakistan \\ bashir_m@hotmail.com
}

\begin{abstract}
This paper presents a stability parametric analysis of a $59 \mathrm{~m}$ high embankment dam. The analysis was performed in order to evaluate the minimum values of strength parameters that satisfy the stability requirements of the dam. The parametric analysis was conducted for three main zones of the dam: upstream shell, core, and downstream shell, which consisted of sandy gravel, clay, and random fill respectively. The friction angles of these materials were gradually decreased in order to represent different soil conditions. It was observed that stability requirements for the end of construction and after the filling of the reservoir could be satisfied if friction angle values of the sandy gravel and the random fill are $34^{\circ}$ and $32^{\circ}$, instead of $37^{\circ}$ and $34^{\circ}$. However, the value of the core's cohesion could be utilized as $30^{\circ}$ without any reduction so that the dam could be safe after the filling of the reservoir. The results of this study could be beneficial to practicing engineers for the design of safe and economical embankment dams.
\end{abstract}

Keywords-embankment dam; slope stability; pore pressure; end of construction; filling of reservoir

\section{INTRODUCTION}

Embankment dams are large structures that require huge volumes of fill materials. Many different sources of fill materials are identified within the boundaries of the embankment dam for economical purposes. In general, different soils from different sources may exhibit varied strength and stiffness properties. It is therefore important to investigate the effect of soil's strength and stiffness properties on the stability of an embankment dam during the design stage, before the actual construction. Therefore, parametric analysis is required in order to evaluate minimum strength and stiffness properties range of soils, which could be utilized for the safe and economical design of embankment dams [1-2]. Pakistan is an agricultural country and its economy mainly depends on the availability of water and hydropower electricity. For this purpose, many dams have been or proposed to be constructed in the near future. In order to ensure the safety of both the existing and the proposed dams in Pakistan, it is necessary to investigate the strength properties of local soils and their effects on the stability of the dams during their service life. There are very few case studies published on the stability issues of dams in Pakistan [3-13]. To the best of our knowledge no parametric analysis on the effects of strength properties on the stability of embankment dams with respect to local site conditions in Pakistan has been published. Therefore, there is a need for more case studies that could address issues related to the safe and economical design of embankment dams, based on parametric analysis of local soils. This is because every dam is considered as a unique structure based on its design, materials used, and foundation geology.

It is estimated that about half of embankment dams' failures have occurred due to the buildup of excess pore pressure, seepage, internal erosion and excessive deformations [10]. These instability problems may occur at routine or unusual conditions (e.g. heavy rainfall, intense earthquake) during the 
service life of an embankment dam [11]. The failure of a dam may cause loss of lives and financial resources. Most slope failures in embankment dams have occurred either during or after the end of construction. The increase of pore water pressure depends on the water content of the fill and on the rate of construction [12]. Due to the low permeability of soils, excess pore pressure might develop gradually during raising and filling of the reservoir. This increase in excess pore pressure may lead to slope instability or dam failure [13].

This paper presents the parametric analysis of the effect of soils' strength properties on the stability of an embankment dam, the Nai Gaj dam. Three main zones, involving large quantities of fill materials, are focused: upstream shell, core, and downstream shell. The Nai Gaj dam is located $65 \mathrm{~km}$ northwest of Dadu, in Sindh Province of Pakistan. Almost 50\% of its construction is already completed. It is estimated that the dam will irrigate about 40,000 acres of land, meeting the water needs of the growers. The catchment area of the dam is $7019 \mathrm{~km}^{2}$ and $85 \%$ of this area lies in Baluchistan, while $15 \%$ lies in Sindh province.

\section{MATERIALS AND METHODS}

The cross section of Nai Gaj dam is shown in Figure 1. The material zones in the dam are: sandy gravel, random fill, central impervious clay core, sand filter, coarse filter and drainage blanket. The foundation of the dam mainly consists of sandy siltstone. This embankment dam is $59 \mathrm{~m}$ high. The dam is $1137 \mathrm{~m}$ long, having a maximum design water level of $56.6 \mathrm{~m}$. The core has an upstream side slope of $1 \mathrm{H}: 3 \mathrm{~V}$, and a downstream slope of $1 \mathrm{H}: 4 \mathrm{~V}$. The upstream and downstream shoulders have slopes $1 \mathrm{~V}: 2.5 \mathrm{H}$. Drainage features, including a chimney drain and horizontal drainage blanket below the downstream shell, have been incorporated in the design to relieve the pore water pressure within the dam body and to dispose the seepage water in a safe manner in order to prevent erosion and boiling. Numerical analysis was carried out on a typical section of the dam. Stability and excess pore pressure analyses were carried out on a two dimensional plane strain condition, using the finite element program Plaxis 2D [14], for two conditions: the gradual raising at the end of construction and after the reservoir filling.

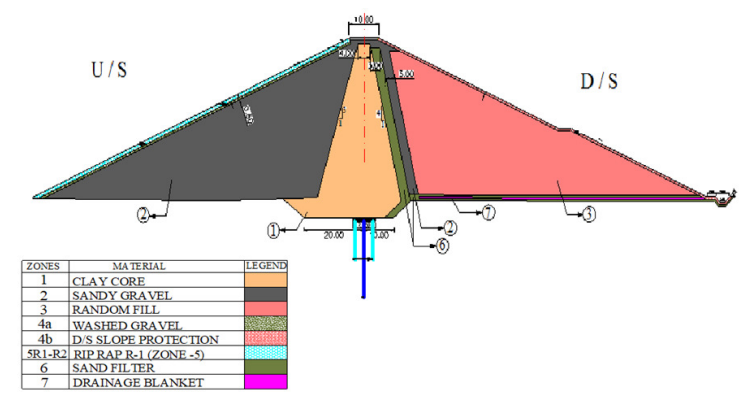

Fig. 1. Cross section of the Nai Gaj dam

Mohr-Coulomb model [15] was used on all layers of the dam for computing the pore pressures and the safety factors at the end of the construction and during the reservoir filling. The material properties of the Mohr-Coulomb model, used for the computation of dam's settlement during the end of construction and the reservoir filling, are presented in Table I. Coupled deformation and consolidation analyses were carried out in order to estimate the development and dissipation of excess pore pressure as a function of time. In addition, safety analysis was conducted to compute the safety factors of the dam. The raising of the embankment of the dam was decided based on the construction work that is being carried out on the site. The dam was mainly raised at a rate of three meters in 30 days.

TABLE I. MATERIALS OF NAI GAJ DAM AND ITS FOUNDATION

\begin{tabular}{|c|c|c|c|c|c|}
\hline $\begin{array}{c}\text { Material } \\
\text { type }\end{array}$ & $\begin{array}{c}\text { Saturated } \\
\text { unit weight } \\
\left(\mathrm{kN} / \mathrm{m}^{3}\right)\end{array}$ & $\begin{array}{c}\text { Cohesion } \\
\left(\mathrm{kN} / \mathrm{m}^{2}\right)\end{array}$ & $\begin{array}{l}\text { Friction } \\
\text { angle } \\
\text { (deg) }\end{array}$ & $\begin{array}{c}\text { Modulus of } \\
\text { elasticity } \\
\left(\mathrm{kN} / \mathrm{m}^{2}\right)\end{array}$ & $\begin{array}{l}\text { Permeability } \\
\text { (m/day) }\end{array}$ \\
\hline Clay & $18.85^{[19]}$ & $9.57^{[19]}$ & $30^{[19]}$ & $50000^{[19]}$ & $0.000263^{[19]}$ \\
\hline $\begin{array}{l}\text { Sandy } \\
\text { gravel }\end{array}$ & $21.5^{[20]}$ & 0 & $37^{[17-19]}$ & $50000^{[24]}$ & $86.4^{[25]}$ \\
\hline $\begin{array}{c}\text { Random } \\
\text { fill }\end{array}$ & $18.85^{[19]}$ & 0 & $34^{[19]}$ & $50000^{[19]}$ & $0.0263^{[19]}$ \\
\hline $\begin{array}{c}\text { Washed } \\
\text { gravel }\end{array}$ & $21.5^{[20]}$ & 0 & $37^{[21-23]}$ & $45000^{[26]}$ & $864^{[23]}$ \\
\hline $\begin{array}{c}\text { D/s slope } \\
\text { protection }\end{array}$ & $19.5^{[32]}$ & 0 & $34^{[21-23]}$ & $40000^{[29-30]}$ & $8640^{[23]}$ \\
\hline Riprap & $19.5^{[19]}$ & 0 & $34^{[19]}$ & $40000^{[29-30]}$ & $8640^{[23]}$ \\
\hline Sand filter & $18.85^{[19]}$ & 0 & $36^{[19]}$ & $40220^{[19]}$ & $26.33^{[19]}$ \\
\hline $\begin{array}{c}\text { Drainage } \\
\text { blanket }\end{array}$ & $21.5^{[20]}$ & 0 & $37^{[21-23]}$ & $45000^{[31]}$ & $864^{[27]}$ \\
\hline $\begin{array}{c}\text { Sandy } \\
\text { siltstone }\end{array}$ & $20.4^{[19]}$ & $12^{[19]}$ & $29^{[19]}$ & $125000^{[31]}$ & $0.00063^{[19]}$ \\
\hline
\end{tabular}

The finite element model of the dam was extended laterally, by $100 \mathrm{~m}$ on each side, in order to minimize the effect of its boundaries, as shown in Figure 2. The finite element mesh consisted of 6619 triangular elements with 53463 nodes. The average element size was $3.2 \mathrm{~m}$. The mesh was sufficiently refined to the extent that with further refinement of the mesh the results were almost the same (Figure 3). Water level in the finite element model is $15 \mathrm{~m}$ below the surface (Figure 2). The highest flood level of $56.6 \mathrm{~m}$ in the finite element model is shown in Figure 4.

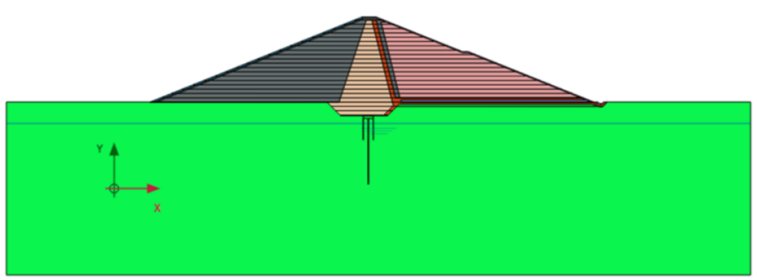

Fig. 2. Finite element model of the Nai Gaj dam

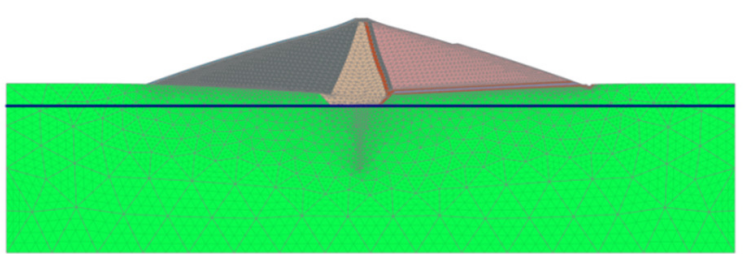

Fig. 3. Finite element mesh of the Nai Gaj dam 


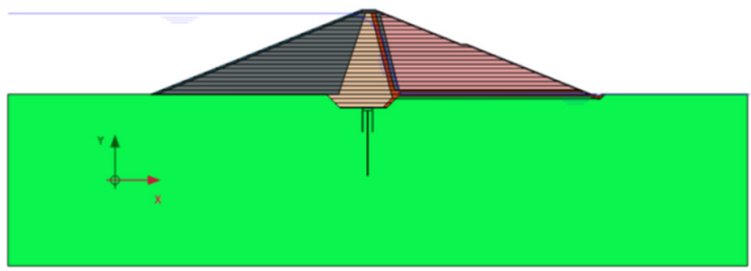

Fig. 4. Maximum water level in the Nai Gaj dam

\section{RESULTS AND DISCUSSION}

\section{A. Excess Pore Pressure}

The magnitude of excess pore pressure increased when the embankment rose up to a level of $45 \mathrm{~m}$ (Figure 5-6). When the embankment rose from $45 \mathrm{~m}$ to $59 \mathrm{~m}$, the excess pore pressure mainly decreased. The reason is that as the dam was raised higher, the width of layers gradually decreased. This indicates that the weight of the top layers of the dam was lower as compared to the bottom layers (Figure 7). This implies that the rate of dissipation of the excess pore pressure was higher compared to the lower rate of loading of the upper layers. Therefore the excess pore pressure decreased with respect to time.

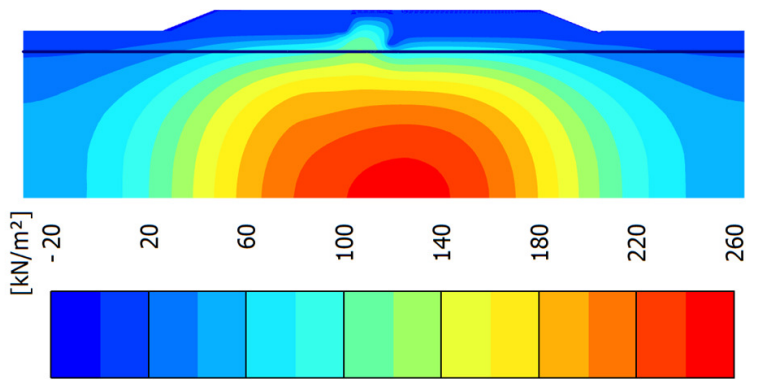

Fig. 5. Development of excess pore pressures at $15 \mathrm{~m}$ raising of the dam

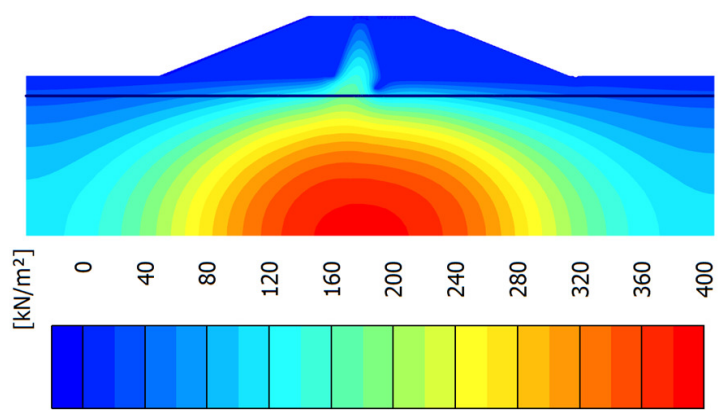

Fig. 6. Development of excess pore pressures at $45 \mathrm{~m}$ raising of the dam

\section{B. Factor of Safety}

Dam's factor of safety was computed to be 1.6 and 1.48 for the end of construction and after the reservoir filling conditions respectively. Due to soils' saturation, the factor of safety after the reservoir filling decreased compared to the end of construction. According to available guidelines [28], the safety factors for the end of construction and the reservoir filling at normal operating level are 1.3 and 1.5 respectively. This implies that the stability of the dam is considered satisfactory for both conditions. Moreover the results of the study for the dam's potential failure zones, for both conditions, are exhibited in Figures 8 and 9. The potential failure zone for the end of the construction was at the upstream side of the dam, while the failure zone after the reservoir filling developed on the downstream side. The modes of failure are consistent with the literature.

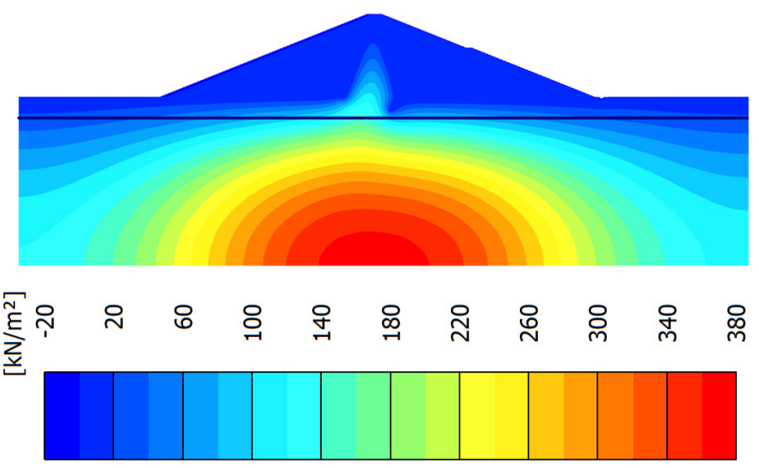

Fig. 7. Development of excess pore pressures at $59 \mathrm{~m}$ raising of the dam

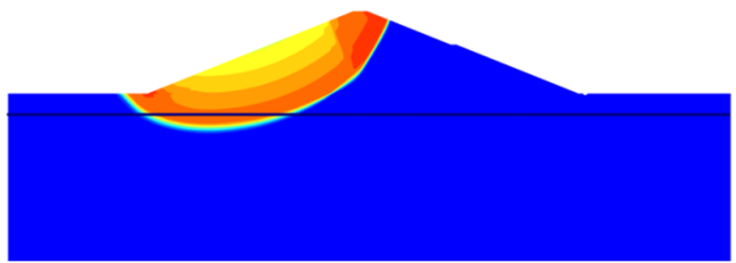

Fig. 8. Potential failure zone of the dam at the end of construction

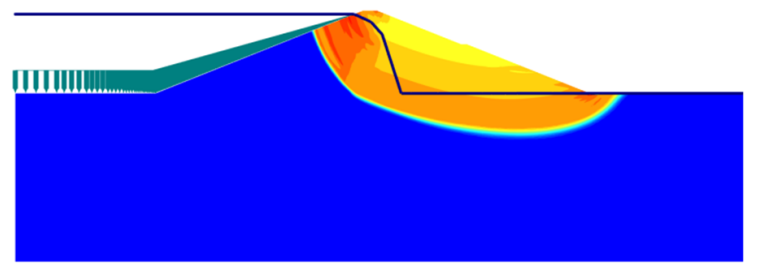

Fig. 9. Potential failure zone of the dam after reservoir filling

\section{Effect of Sandy Gravel's Friction Angle on Safety Factor}

The upstream shell of the dam consists of sandy gravel and the effect of its friction angle on the dam safety factor was examined (Figure 10). As expected, dam's safety factor increased with increasing values of the sandy gravel's friction angle. For both conditions, the stability of the dam is satisfactory if the minimum value of sandy gravel's friction angle is $34^{\circ}$ This implies that the friction angle value of the sandy gravel could be taken as $34^{\circ}$ instead of $37^{\circ}$. 


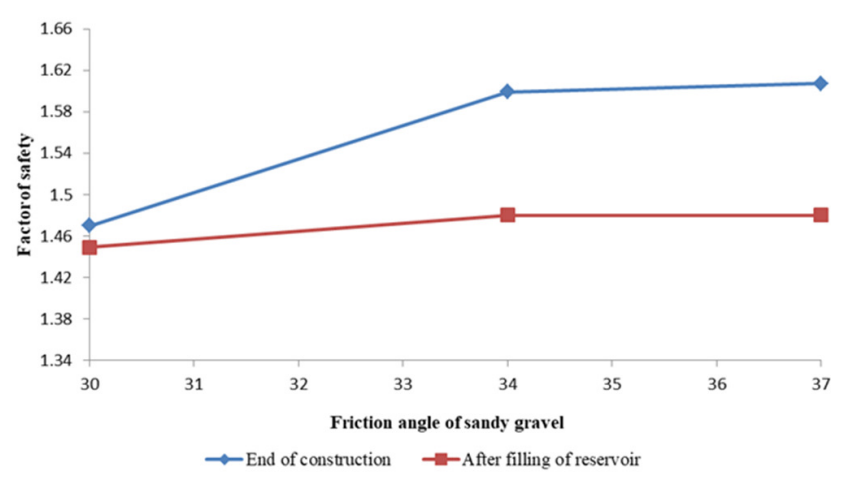

Fig. 10. Effect of sandy gravel's friction angle on dam's safety factor

\section{Effect of Random Fill's Friction Angle on Safety Factor}

The downstream shell of the dam consists of random fill material and its friction angle effect on dam's safety factor was analyzed (Figure 11). As expected, dam's safety factor increased with increasing values of random fill's friction angle. For post reservoir-filling conditions, increasing this friction angle to over $32^{\circ}$ has no influence on the safety factor. This implies that random fill's friction angle could be taken as $32^{\circ}$ instead of $34^{\circ}$.

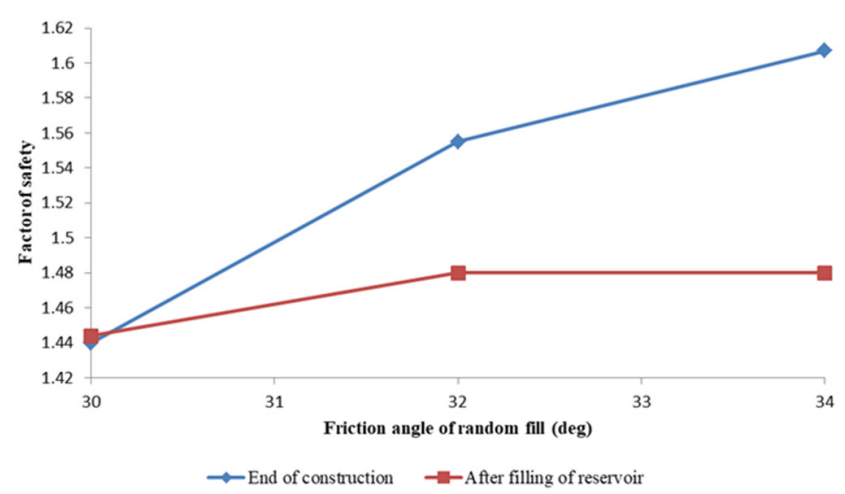

Fig. 11. Effect of friction angle of random fill on safety factor of the dam

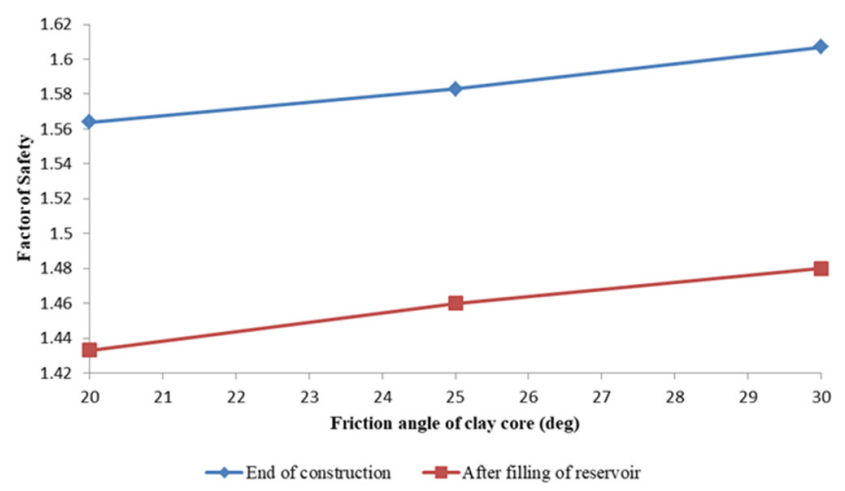

Fig. 12. Effect of friction angle of clay core on safety factor of the dam

\section{E. Effect of Clay Core's Friction Angle on Safety Factor}

The center of the dam consists of clay core material and its friction angle effect on the stability of the dam was investigated
(Figure 12). As expected, dam's safety factor increased with increasing values of clay core's friction angle for both conditions. In partially dry state, the core was stronger and dam's safety factor was more than sufficient, even for friction angles at $20^{\circ}$. However, clay is more sensitive to saturation, so the cohesion of the core decreases when moisture content increases. Therefore, in order to increase the stability of the dam, it is necessary to fully compact the core and utilize the maximum value of cohesion, which is $9 \mathrm{kPa}$.

\section{CONCLUSION}

In this study, the slope stability behavior of an embankment dam was analyzed, by investigating the effects of various materials, in different zones. The friction angles of the three main zones, sandy gravel, clay core, and random fill, of the embankment dam were gradually decreased. It was found that the stability of the dam was satisfactory for both the end of construction and after the reservoir filling conditions, if the minimum friction angle values of the sandy gravel and the random fill are decreased respectively from $37^{\circ}$ to $34^{\circ}$ and from $34^{\circ}$ to $32^{\circ}$. For the dam to be stable after the filling of the reservoir, it is necessary to utilize the same value $\left(30^{\circ}\right)$ of clay core. Those results could be valuable for practicing engineers working on safe and economical design of embankment dams.

\section{ACKNOWLEDGMENT}

The authors would like to thank Water and Power Development Authority (WAPDA) Pakistan for their permission and the dam's data provision.

\section{REFERENCES}

[1] J. T. Christian, C. C. Ladd, G. B. Baecher, "Reliability applied to slope stability analysis", Journal of Geotechnical Engineering, Vol. 120, No. 12, pp. 2180-2207, 1994

[2] A. S. Al-Homoud, N. Tanash, "Modeling uncertainty in stability analysis for design of embankment dams on difficult foundations", Engineering Geology, Vol. 71, No. 3-4, pp. 323-342, 2004

[3] F. S. Khan, A. A. Malik, "Probability and sensitivity analysis of the slope stability of Naulong dam", Pakistan Journal of Engineering and Applied Sciences, Vol. 13, pp. 54-64. 2016

[4] K. Farooq, H. Mujtaba, A. Nazir, A. H. Khan, "Effectiveness of upstream blanket and grouting in control of seepage at khanpur dam project”, Pakistan Journal of Science, Vol. 65, No. 2, pp. 228-233, 2013

[5] M. S. Khan, T. A. Gilani, M. A Gul, "Post impounding problems and management measures in carbonate geology at Khanpur dam project, Pakistan”, Science International (Lahore), Vol. 23, No. 2, pp. 129-134, 2011

[6] I. A. Jamali, U. Mortberg, B. Olofsson, M. Shafique, "A spatial multicriteria analysis approach for locating suitable sites for construction of subsurface dams in Northern Pakistan", Water Resources Management, Vol. 28, No. 14, pp. 5157-5174, 2014

[7] Y. S Khalil, M. Arif, H. A. Bangash, M. Sajid, N. Muhammad, "Petrographic and structural controls on geotechnical feasibility of dam sites: implications from investigation at Sher Dara area (Swabi), northwestern Pakistan", Arabian Journal of Geosciences, Vol. 8, No. 7, pp. 5067-5079, 2015

[8] M. Hieatt, S. R. Abbas Shah, R. A. Khan, M. Ali, N. Asghar, S. Sheikh, I. A. Humayun, P. J. Mason, J. D. Molyneux, G. R. Khan, I. A. Humayun, "Some geotechnical aspects of raising the Mangla dam, Pakistan", Proceedings of the Institution of Civil Engineers Geotechnical Engineering, Vol. 165, No. 3, pp. 127-141, 2012

[9] Y. Honjo, P. H. Giao, P. A. Naushahi, "Seepage analysis of Tarbela dam (Pakistan) using finite element method", International Journal of Rock 
Mechanics and Mining Sciences and Geomechanics Abstracts, Vol. 32, No. 3, Article ID 131A, 1995

[10] I. Arshad, M. M. Babar, "Finite element analysis of seepage through an earthen dam by using geo-slope (SEEP/W) software", International Journal of Research, Vol. 1, No. 8, pp. 619-634, 2014

[11] I. Arshad, M. M. Babar, "Comparison of SEEP/W Simulations with field observations for seepage analysis through an earthen dam (case study: Hub Dam - Pakistan)", International Journal of Research, Vol. 1, No. 7, pp. 57-70, 2014

[12] A. H. Bhutto, S. Zardari, M. A. Zardari, G. S. Bhurgri, B. A. Memon, R. Bhanbhro, M. M. Babar, "Mohr-Coulomb and hardening soil model comparison of the settlement of an embankment dam" , Engineering, Technology \& Applied Science Research, Vol. 9, No. 5, pp. 4654-4658, 2019

[13] A. H. Bhutto, S. Zardari, G. S. Bhurgri, M. A. Zardari, R. Bhanbhro, B. A. Memon, "Post construction and long term settlement of an embankment dam computed with two constitutive models", Engineering, Technology \& Applied Science Research, Vol. 9, No. 5, pp. 4750-4754, 2019

[14] M. Foster, R. Fell, M. Spannagle, "The statistics of embankment dam failures and accidents", Canadian Geotechnical Journal, Vol. 37, No. 5, pp. 1000-1024, 2000

[15] E. Panulinova, S. Harabinova, "Methods for analyzing the stability of an earthen dam slope", Advanced Materials Research, Vol. 969, pp. 245248,2014

[16] S. Ozcoban, M. M. Berilgen, H. Kilic, T. B. Edil, I. K. Ozaydin, "Staged construction and settlement of a dam founded on soft clay", Journal of geotechnical and geoenvironmental engineering, Vol. 133, No. 8, pp. 1003-1016, 2007

[17] D. T. Bergado, C. Teerawattanasuk, "2D and 3D numerical simulations of reinforced embankments on soft ground", Geotextiles and Geomembranes, Vol. 26, No. 1, pp. 39-55, 2008

[18] R. B. J. Brinkgreve, PLAXIS reference manual, PLAXIS, 2017

[19] WAPDA, Project Planning Report of Nai Gaj Dam, Water And Power Development Authority Pakistan, 2006

[20] A. J. Schleiss, R. M. Boes, Dams and reservoirs under changing challenges, CRC Press, 2011

[21] M. Carter, S. P. Bentley, Soil properties and their correlations, John Wiley \& Sons, 2016

[22] F. Cobb, Structural engineer's pocket book, British standards edition, Elsevier, 2008

[23] R. F. Craig, Soil mechanics, Springer, 2013

[24] R. A. Rajapakse, Geotechnical engineering calculations and rules of thumb, Butterworth-Heinemann, 2015

[25] G. E. Barnes, Soil mechanics: principles and practice, Palgrave MacMillan, 2010

[26] J. L. Justo, J. Saura, "Three dimensional analysis of Infiernillo dam during construction and filling of the reservoir", International Journal for Numerical and Analytical Methods in Geomechanics, Vol. 7, No. 2, pp. 225-243, 1983

[27] B. G. Look, Handbook of geotechnical investigation and design tables, CRC Press, 2014

[28] M. N. Sara, Site assessment and remediation handbook, CRC Press, 2003

[29] P. J. Burgess, D. Sarabia, J. Small, H. G. Poulos, J. Sinha, "Settlement behaviour of a major dam”, Ancold bulletin, Vol. 137, pp. 91-100, 2007

[30] L. Ormann, M. A. Zardari, H. Mattsson, A. Bjelkevik, S. Knutsson, "Numerical analysis of strengthening by rockfill embankments on an upstream tailings dam", Canadian Geotechnical Journal, Vol. 50, No. 4, pp. 391-399, 2013

[31] D. U. Deere, R. P. Miller, Engineering classification and index properties for intact rock, University of Illinois at Urbana, 1966

[32] R. Fell, P. MacGregor, D. Stapledon, G. Bell, M. Foster, Geotechnical engineering of dams, CRC press, 2014 